\title{
A Systematic Review about an Advance in Cyclosporine Monitoring in Kidney Transplant Recipients
}

\author{
Behzad Einollahi, ${ }^{1}$ and Mojtaba Teimoori ${ }^{2,}{ }^{*}$ \\ ${ }^{1} \mathrm{MD}$, Professor of Nephrology, Head of Nephrology and Urology Research Center, Baqiyatallah University of Medical Sciences, Tehran, IR Iran \\ ${ }^{2} \mathrm{MD}$, Urology Resident, Guilan University of Medical Sciences, Rasht, IR Iran \\ Corresponding author: Mojtaba Teimoori, MD, Urology Resident, Guilan University of Medical Sciences, Rasht, IR Iran. E-mail: mojtaba_teimoori@irimc.ir
}

Received 2014 December 07; Revised 2015 August 05; Accepted 2017 February 25.

\begin{abstract}
Context: An immunosuppressive drug, Cyclosporine (CsA), has been commonly used in kidney transplants. A safe dosing of CsA often causes nephrotoxity, bone marrow toxicity, and infection. Pharmacokinetic characteristics of CsA and CsA marker relation to the immune suppression have not been completely described in clinical practices yet.

Objectives: This review summarizes our achievements on pharmacokinetic and CsA level Marker in kidney transplant patients. Search methods and Selection criteria: A literature review was done using the National Center for Biotechnology Information's Pubmed Medline, Ovid Medline and Embase, and Iranian registries (Iranmedex, SID, MagIran, and IranDoc). Titles and abstracts were then reviewed to select studies based upon the predefined inclusion criteria. Our study defined a population of adult solid organ transplant recipients receiving the cyclosporine that Cyclosporine monitoring was done.

Data Collection and Analysis: Two reviewers independently appraised the quality of each trial and extracted the data from the included trials.

Results: CsA pharmacokinetics is very different between kidney transplant recipients, in order to CsA profiling, no pharmacodynamic tools has been confirmed yet in clinical practices and the best way to individualize calcineurin inhibitor therapy is still a controversial issue. Co levels do not exactly predict the CsA level or rejection risk, patient monitored by C2 levels have upper doses of CsA and have a lower frequency of early acute allograft rejection than patients profiled with CO and although CA is highly heterogeneous closely post-transplant and seems to be unhelpful early after post-transplant it is more favorable after first months after. Conclusions: Establishing a biological CsA marker may be helpful in clinical decisions on the dose. It seemed to be logical that we should re-inspect the possibility of using them as a supplementary tool towards better therapeutic drug monitoring of cyclosporine or it needs to be reevaluated and needs to find a new target for a therapeutic plan in kidney transplant patients.
\end{abstract}

Keywords: Cyclosporine, Monitoring, Kidney Transplant

\section{Context}

Cyclosporine A (CsA) is an immunosuppressant drug extensively used in organ transplant patients to reduce the rejection rate. At first this drug is isolated from the fungus Tolypocladium inflatum isolated from a soil sample obtained by Sandoz scientists at Hardangervidda, Norway in 1969 (1). Cyclosporine is a cyclic nonribosomal peptide of 11 amino acids and contains a single D-amino acid, which are rarely encountered in nature (2). The immunosuppressive effect of CsA was discovered on 1972.The success of CsA in preventing organ rejection was shown in kidney transplants by Calne (3) and in liver transplants performed by Starzl et al. (4). CsA bind to the cytosolic protein cyclophilin of immunocompetent lymphocytes, particularly T-lymphocytes. This complex of cyclosporine and cyclophilin inhibits Calcineurin, which, under normal circumstances, is responsible for activating the transcription of interleukin 2. Calcineurin then dephosphorylates the transcription factor NF-AT (nuclear factor of activated T- cells), which moves to the nucleus of the T-cell and increases the activity of genes coding for IL-2 and related cytokines. Cyclosporine inhibits the dephosphorlyation of NF-AT by binding to cyclophilin (5). It also inhibits lymphokine production and interleukin release and, therefore, leads to an increase in function of effector T-cells. Its believed that CsA cause its effects by directly binding to the cyclophilin D protein that constitutes part of the mitochondrial permeability transition pore and by preventing the Calcineurin phosphatase pathway (6-8).

Ever since the discovery of CsA, graft failure with acute rejection incidence has decreased and patient survival enhanced (9). The Calcineurin inhibitors (CNIs), especially CsA, have had a great effect on the overall achievement of kidney transplantations favorable outcome and CsA is the most important immunosuppressive drug currently used for kidney transplants (10). CsA is the base of many immunosuppressant practices all around the world. Therapeutic monitoring of the CsA is important due to the fact 
that this drug has a constricted therapeutic range with severe probable side effects. Nonetheless after close observation, significant sets of transplant patients have acute rejection or CsA nephrotoxicity in spite of the CsA blood level upkeep within the recommended dosage, which is different in any center $(11,12)$. For example CsA nephrotoxicity is a major reason for chronic kidney dysfunction. Accurate dosing of CsA is key because of the need to adequate blood level of CsA for avoiding kidney rejection; in a slim therapeutic level in this patient group. In count, exact dose administration of CsA and its nephrotoxicity are the 2 other issues related to CsA (13) that can be an independent hazard issue for graft loss and mortality after kidney transplantation. Furthermore, mortality outcomes from cardiovascular disease, infection, and malignancies are important reasons for CsA, which this drug can cause indirectly (14). Therefore, the search for an optimal CsA dosage continues to be essential (15). Although, the best evident clinical marker of CsA effectiveness is the measurement of kidney function and graft histology and the individualized treatment targets can be based on the patient's and his graft's medical history (16), however it is interventional and seems to not be practicable. However, CsA level observing is essential (17).

Best CsA level achievement in kidney transplant recipients is tough because of inconsistency in CsA metabolites and ethnic factors (18), Furthermore, to this there are some other basic problems in field of CsA monitoring; the main concern is analytical method for CsA measurement. Currently, there are 6 analytical techniques for CsA monitoring and numerous are in advance (19-21). These analytical methods vary in their accuracy and specificity, and it showed that the 2 methods can be as much as $57 \%$ different in average or can be much larger, depending on such factors as transplant type, the time after transplantation, and liver function (22).

Second; CsA concentrations in extracellular or wholeblood fractions is different and measurement of wholeblood or extracellular blood concentrations does not necessarily offer an exact and reproducible image of intracellular CsA level within T cells. For example, CNIs in whole blood are highly bound to erythrocytes and lipoproteins. However, inter- and intra-patient differences of these strictures have been shown to affect CNI concentrations in lymphocytes $(23,24)$. Evidence supports the theory that T-cell suppression is the key mechanism by which CNIs achieve immune suppression therefore $T$ cells are interesting candidates for pharmacodynamics-monitoring tools (25).

Third; there are many confounding variables such as meals, patients who take CsA with meals sometimes or at fasting may have change in CsA blood level, which could result in to under- or overdosing (26).
Another factor that could pointedly disturb CsA blood level is the CsA transporters, similar to most immunosuppressive drugs that have substrates for one or more drug transporter proteins; such as P-glycoprotein, that are expressed on T cells $(24,27)$. Intracellular CsA absorptions can consequently be changed by cellular drug-exporting activities. Pharmacokinetic outlines and drug-drug interactions at this level are not monitored by current CsA level measurement. To more accurate level determination, intracellular T-cell drug concentration assays have been established (28). CsA levels are used as a replacement marker of kidney function, but do not certainly display a relationship with pharmacological response (29).

\section{Methods}

This review aimed to evaluate the cyclosporine A monitoring in patients who underwent kidney transplant. We intended to the best method for cyclosporine A monitoring. More specifically, this review intended to answer the following relevant questions:

1. Is cyclosporine A monitoring effective in in kidney transplant?

2. What cyclosporine A monitoring method in conventional methods are best?

3. What is new about cyclosporine A monitoring?

\subsection{Criteria for Considering Studies for This Review}

\subsubsection{Types of Studies}

Randomized clinical trials comparing the addition of cyclosporine A to standard treatment in kidney transplant patients. Trials were included irrespective of publication status, language, and blinding.

\subsubsection{Types of Participants}

Adult kidney transplant patients (18 + years of age).

\subsubsection{Types of Interventions}

Intervention: Cyclosporine A was considered, regardless of the mode of administration.

\subsubsection{Types of Outcome Measures}

The number of patients with kidney transplants who treated with cyclosporine A monitoring was used as the outcome measure of interest. The definition of suppression was based on the modified vilko (30). The primary outcome asses' best monitoring method that preserving transplanted kidney. Secondary outcome measures included: 1 . the number of deaths; 2 . the number of patients who raised creatinine; and 3. adverse events. Adverse 
events included: 1 . any serious adverse events that were fatal, life-threatening, or requiring in patient hospitalization or prolongation of existing hospitalization with regard of monitoring methods; 2 . any adverse events that resulted in significant disability or in capacity; 3 . any important medical events that might not be immediately life-threatening or resulted in death or hospitalization, but might jeopardize the patient or required intervention to prevent one of the above outcomes with regard of monitoring methods; and 4. any adverse events that required discontinuation of medication with regard of monitoring methods.

\subsection{Search Methods for Identification of Studies}

A literature review was done using the National Center for Biotechnology Information's Pubmed Medline, Ovid Medline and Embase, and Iranian registries (Iranmedex, SID, MagIran, and IranDoc). Search terms were broad and equivalent for each database, specifically for literatures studying Cyclosporine trough level or Cyclosporine 2 hours post dose blood level monitoring in adult human solid organ transplantation from 1970 up to now. Preliminary search results were reviewed for duplication. Titles and abstracts were then reviewed to select studies based upon the predefined inclusion criteria. These defined a population of adult solid organ transplant recipients receiving the cyclosporine, in which a Cyclosporine monitoring was done.

\section{Results}

\subsection{Co Value}

First suggested tools for CsA blood level monitoring was the determination of trough levels (C0) (17). The oldest tools of CsA blood level monitoring, the Co level is commonly used even to date (31-33). Although it seems Co is useful to predict CsA side effects $(34,35)$, the use of CO is led to debates. Co did not closely reveal the drug dose and blood levels varied even in inter and intra individually. Changes in dose need frequent testing after to guarantee its detection. Consideration of the delay should help in the modification of doses (36). Some researcher commented that CsA trough level had no direct relation with CsA side effects and it is not an appropriate tool for drug side effects assessment (37). Hegazy SK showed CsA trough levels increased during bacterial and fungal infections and returned to pre-infection levels once the infection was resolved (38). It has long been accepted that the results of Co checking are suboptimal, and litterateurs in field of transplantation about Co has shown that area under the concentration-time curve (AUC0-12h) and Cmax (maximum concentration) have more beneficial relations with the sufficiency or toxicity occurrences than Co $(17,39)$, Co monitoring does not necessitate narrow a therapeutic window as C2 monitoring and may lead to unnecessary dosage adjustments and cause in over or under dosage underestimation (40-42). However, it seems that the overall Co level shows only a weak correlation with rejection $(43,44)$.

\subsection{Why Use C2 Monitoring in Kidney Transplantation Patients?}

After that, CsA 2-hour post-dose level (C2) monitoring has been stated to be greater beneficial in predicting consequences (17). In a Consensus suggested C2 monitoring is the best single time-point predictor, which is the greatest inter individual variability of CsA pharmacokinetics and the best alternate for Cmax, and which agrees with the period of maximal Calcineurin inhibition $(17,39)$. However, evidence of $\mathrm{C} 2$ monitoring in stable renal transplant patients is limited. Most of this finding comes from studies that there are not clinical trials and most of them assess switching method C0 to C2 (32, 45-47). However, the technique is more critical, but immunoassay bias is lower with C2 than with C0 (31). Pharmacokinetic monitoring of C2 quickly has changed from experimental pharmacology to routine clinical practice. These techniques have now been extensively validated, and appear to offer important and immediate therapeutic, in most clinical policies all over the world (48). Approvals for use of C2 monitoring for clinical treatment were established to be furthermore reviewed $(17,49)$. The clinical advantages of C2 profiling are not limited to Kidney transplantation, but use to all solid organs so far transplanted (50) for example in a study showed that prospective comparison has established a highly significant correlation between $\mathrm{C} 2$ and AUC0-6 in liver transplantation (51). An international multi center randomized trial has been definite that acute rejection is lower in transplanted kidney recipients monitored by C2 than Co levels (52). In maintenance liver and heart recipients, Cantarovich and colleagues $(13,53)$ have shown a beneficial effect of C2 than CO in relation of AUCO-4 (54).

CsA possibly will increase (55) or decrease (56) drug blood level by the induction or inhibition of metabolic enzyme. In-vitro studies have shown that the concentration of CsA within the dosing interval is in reverse correlation to lymphocyte Calcineurin activity or IL-2 production (40, 57). The maximum inhibition of these parameters happens 2 hours after dosing, with the peak concentration of CsA in peripheral blood. One caution concerning the $\mathrm{C} 2$ values assayed is although may not always be evaluated most effectively (58).

Data regarding C2 profiling prospectively examined risks and benefits are rare in renal transplant recipients. Experience with $\mathrm{C} 2$ monitoring in maintenance patients are little, a study established that an satisfactory C2 level 
soon after transplantation is accompanying with a decreased risk of acute rejection in adult renal transplant recipients not in maintenance phase. In the maintenance phase, although mean $\mathrm{C} 2$ levels do not seem to identify patients at risk of rejection, it may help to identify too much immunosuppression and improve long-term survival by decreasing CsA toxicity (59).

For cyclosporine C2 monitoring, blood should be drawn within 15 minutes of the 2-hour post dose time point (26) that any delay may cause bias in level estimation. On the other hand there are studies that revealed that in C2 monitored patients, $\mathrm{C} 2$ levels are not predictive for the incidence of early allograft rejection (60). However, more studies showed that $\mathrm{C} 2$ relates with AUC0-4 in kidney transplanted patients (61), as has been reported in heart (53, 62) and liver (13) transplantation, although this correlation can be impaired by concomitant administration of Diltiazem (63).

\subsection{Max and 3-Hour Cyclosporine Blood Level Monitoring}

Some study suggest that cyclosporine blood level after 3 hours may represent a better method of monitoring cyclosporine dose than cyclosporine trough blood level. Cyclosporine blood level 3 hours after renal transplantation is closely associated with acute rejection and cyclosporine nephrotoxicity (64). The highest concentration of CsA (C max) is believed to reveal the time point of maximal Calcineurin inhibition in response to CsA $(49,65,66)$. To our knowledge there is little study to show a correlation of a C max and 3-hour CsA blood level monitoring post-dose CsA concentration with acute rejection and nephrotoxicity in kidney transplant recipients. CsA blood level after 3 hours may be a better tool than cyclosporine trough blood level. However, safety and efficacy require a formal prospective randomized study (64). C max and 3-hour cyclosporine blood level have their limitation like meals confounding factor, for example, meals can decline the Cmax and AUC of $\operatorname{CsA}(67,68)$.

\subsection{Area Under the Curve Monitoring}

There has been a different method of therapeutic drug profiling for optimizing CsA dosing in kidney transplant recipients, however, it showed that whole exposure to CsA, as reflected by the area under the concentration-time curve (AUC), was a better outcome predictor than single point (trough) CsA blood level (17). To provide a more exact CsA level monitoring, AUC used in different times after dosing, however, the most valuable AUC timing for CsA is AUCo12 (69). Restricted AUC of CsA like AUC 0 - 6 after CsA administration have shown to improve clinical outcomes, especially than single point $(51,61,64)$. CsA AUC for $0-4$ hours (AUC0-4) also offers valuable information regarding the CsA blood level $(10,69)$. A study established that CsA blood level for AUC0-4 allied well with the entire AUC 012. However, a study showed AUCO -4 and Co levels correlated poorly with AUCO - 12 (70) against other studies that showed AUC0-4 accompanied with better clinical results $(61,71)$. However, the area under the curve of blood CsA level versus time is a better monitoring tool than CsA point profiling $(72,73)$.

Although AUC can be assessed CsA exposure better with stronger power for outcome prediction has a limited sampling approach (74-76), it seems clinical application is impracticable, and it wants several blood sampling $(10,69)$ also, another problem is the costs related with sampling and analysis (64). However, it showed that levels above the threshold of about AUC 0 - 4 are desirable to minimize the risk of rejection (77) and seems because the difference in CsA is highest in AUC 0 - 4 (58). Some new research showed some estimators able to predict cyclosporine AUC0-12h in patients using only 3 blood with minimal bias and may be combined to increase the reliability of CsA dose adjustment in routine (78).

\subsection{Relative Importance of Attaining Cyclosporine Absorption}

The CsA absorption ( $\mathrm{C} 2 / \mathrm{Co}$ or $\mathrm{CA}$ ) phase is important for inhibition of the T-cell and it relates to the concentration of the CsA move in T cells (79). Differences in CA have an important effect in preventing nephrotoxicity (79) CA is effected by small intestine absorption, and it showed that CYP3A4 and PGP activity over time post-transplant changes (80) and CA may change and be in control of CYP3A4 and Pglycoprotein (81-85). CA varies greatly and immediately after transplantation and CsA absorption increases throughout the first 2 weeks (77). It showed that mutual use of $\mathrm{CO}$ and C2 may have beneficial for CsA profiling because interprets both the absorption and the elimination phase (79) and some study suggested C2/C0 ratio. Mutual use of C2 and $\mathrm{CO}$ as a CA profiling have better efficacy than $\mathrm{Co}$ alone $(59,86)$.

Some study concluded that it's better to start absorption profiling to prevent any nephrotoxicity and It declared that the mixture of $\mathrm{C} 0$ and $\mathrm{C} 2$ ( $\mathrm{C} 2 / \mathrm{CO}$ or $\mathrm{CA}$ ) provided good correlation with AUC 0-12 (70). However, literatures in this field are rare and seems that Pharmacodynamics policies and Prospective Randomized clinical trials is needed to be designed to address this question. Results of an analysis indicate that CsA monitoring with CA throughout the early post-transplant phase reduced the risk of rejection than $\mathrm{CO}$ alone like other trials in stable renal transplant patients $(45,53,87)$ heart $(53,54)$, liver $(13,88)$, and lung $(89,90)$ transplant recipients. Twin use of C2 and C0 
offers furthermore evidence for dosing decisions, mainly throughout the early post-transplant period (91).

\subsection{Individualizing Target Range and Adjusting Dose of Cy- closporine}

Kidney transplant recipients show clinical variation in in response to CsA, it presumed some proteins are involved in charge that called CNI binding proteins immunophilins. It suggested that the nuclear factor of activated T-cells (NFAT) reduce after Calcineurin inhibition; genetic polymorphisms in the encoding NFAT genes could also be reasons for variation in CsA efficacy and toxicity. Also, CsA metabolites and their different organ delivery may possibly be another reasons (92). Additionally, enzymes are responsible; the most important enzyme in CsA hepatic metabolism is cytochrome P450 3A4 (93). It showed that a CsA level is mainly influenced by CYP3A4, CYP3A5 and MDR- 1 genes. Patient's differences in clinical response recognized to SNPs in these genes, homozygous mutant patients for CYP3A5 and MDR-1 gene SNPs respond to CsA with lower CsA dosing (94). Although CYP3A5*3 difference is in some different degree, and influence on CO and CsA daily dosing, it seems genetic variation has little effect on the acute rejection rate in kidney transplant recipient (95). Environmental combined genetically factors also play an important role; literatures have shown that vitamin D may up-regulate the expression of the CYP3A4 gene and patient vitamin D low levels is highly in need of on sunlight and show excessive geographical and seasonal inconsistency (93). It revealed that sensitivity to CsA has inter-individual difference, and is higher in transplant recipients than in normal controls. While the molecular description for finding is not comprehended, it seems to be isolated from genetic (96). Very different genetic markers such as HLA, POR*28 allele, ABCB1, NFKB1, and many more genotypes (97-99) play a great role in disease and CsA level $(98,100)$, which seem to be of clinical significance. Therapeutic CsA monitoring is still need to adjust CsA dosing after administration of individualized doses (18) also time, other medication and sex differences in cyclosporine pharmacokinetics and $\mathrm{ABCB} 1$ gene expression in mononuclear blood cells in African American and Caucasian renal transplant recipients has great impact on CsA blood level that attenuate significance of individual therapy (101103). Some data suggests more attention to genetically like NFAT (104) Sommerer C showed NFAT-monitoring has the potential to support pharmacokinetic monitoring during the early post-transplant period (105), however, others like Moes says that dose individualization of Cyclosporine A based on CYP3A4*22 is not indicated (106). Altogether individual therapy such as the NONMEM (107) model might be helpful.

\section{Discussion}

In conclusion, optimized CsA monitoring is very important to reach acceptable blood levels with reducing the risk of unbeneficial episodes such as allograft dysfunction $(105,108)$, CsA pharmacokinetics is very different between kidney transplant recipients, mainly in patients with different kidney disease etiologies (109) such as race, different sex, etc. In order for CsA profiling, no pharmacodynamics tools have been confirmed yet in clinical practice (110) and the best way to individualize Calcineurin inhibitor therapy is still a controversial issue. Despite severe assess for improving graft consequence by CsA monitoring policies, acute rejection events and side effects cannot be prevented (111). Co levels do not exactly predict CsA levels or rejection risk (77), patients monitored by C2 levels have upper doses of CsA and have a lower frequency of early acute allograft rejection than patients profiled with Co (60) and although C2 is highly heterogeneous closely post-transplant and seems to be unhelpful early after post-transplant it is more favorable after the first months after transplantation (77), however, none of them do not take in account genetically environmental factors and may be useless in predicting allograft function. Establishing biological CsA markers may be helpful in clinical decisions on the dose (111). It seemed to be logical that we should re-inspect the possibility of using them as a supplementary tool towards better therapeutic drug monitoring of cyclosporine or it needs to reevaluate and find new targets for a therapeutic plan in kidney transplant patients (112).

Although pharmacokinetic and pharmacodynamics CsA profiling has improved over the past few years, clinical evidence is poor, CsA monitored on C2 have become the basis of immunosuppression in most countries early post-transplant and in first months after transplantation CA may have an more important role in CsA monitoring after early post-transplant period, allied with very low rejection rates. These tools could probably be enhanced additional by the means of more attention to genetically and environmental factors and results in treatment personalization in kidney, before such monitoring can be reached, more evidence is needed. Persistent studies should also be done for an improved degree of knowledge regarding CsA pharmacogenetics and pharmacodynamics in order for better drug monitoring (113).

\section{References}

1. $\mathrm{Wu} \mathrm{AH}$. Creatine kinase isoforms in ischemic heart disease. Clin Chem. 1989;35(1):7-13. [PubMed: 2642764].

2. Borel JF. History of the discovery of cyclosporin and of its early pharmacological development. Wien Klin Wochenschr. 2002;114(12):433-7. [PubMed: 12422576]. 
3. Pritchard DI. Sourcing a chemical succession for cyclosporin from parasites and human pathogens. Drug Discov Today. 2005;10(10):688-91. doi: 10.1016/S1359-6446(05)03395-7. [PubMed: 15896681].

4. Starzl TE, Klintmalm GB, Porter KA, Iwatsuki S, Schroter GP. Liver transplantation with use of cyclosporin a and prednisone. $N$ Engl J Med. 1981;305(5):266-9. doi: 10.1056/NEJM198107303050507. [PubMed: 7017414].

5. Ganong WF, Ganong W. Review of medical physiology. Appleton \& Lange Norwalk, CT; 1995

6. Mott JL, Zhang D, Freeman JC, Mikolajczak P, Chang SW, Zassenhaus HP. Cardiac disease due to random mitochondrial DNA mutations is prevented by cyclosporin A. Biochem Biophys Res Commun. 2004;319(4):1210-5. doi: 10.1016/j.bbrc.2004.05.104. [PubMed: 15194495].

7. Handschumacher RE, Harding MW, Rice J, Drugge RJ, Speicher DW. Cyclophilin: a specific cytosolic binding protein for cyclosporin A. Science. 1984;226(4674):544-7. [PubMed: 6238408].

8. Youn TJ, Piao H, Kwon JS, Choi SY, Kim HS, Park DG, et al. Effects of the calcineurin dependent signaling pathway inhibition by cyclosporin A on early and late cardiac remodeling following myocardial infarction. EurJ Heart Fail. 2002;4(6):713-8. [PubMed: 12453541].

9. Cheung A, Menkis AH. Cyclosporine heart transplantation. Transplant Proc. 1998;30(5):1881-4. [PubMed: 9723320].

10. Nemati E, Einollahi B, Taheri S, Moghani-Lankarani M, Kalantar E, Simforoosh N, et al. Cyclosporine trough (CO) and 2-hour postdose (C2) levels: which one is a predictor of graft loss? Transplant Proc. 2007;39(4):1223-4. doi: 10.1016/j.transproceed.2007.02.005. [PubMed: 17524938].

11. Nankivell BJ, Hibbins M, Chapman JR. Diagnostic utility of whole blood cyclosporine measurements in renal transplantation using triple therapy. Transplantation. 1994;58(9):989-96. [PubMed: 7974738].

12. Oellerich M, Armstrong VW, Schutz E, Shaw LM. Therapeutic drug monitoring of cyclosporine and tacrolimus. Update on Lake Louise Consensus Conference on cyclosporin and tacrolimus. Clin Biochem. 1998;31(5):309-16. [PubMed: 9721427].

13. Cantarovich M, Barkun JS, Tchervenkov JI, Besner JG, Aspeslet L, Metrakos $\mathrm{P}$. Comparison of neoral dose monitoring with cyclosporine through levels versus 2-hr postdose levels in stable liver transplant patients. Transplantation. 1998;66(12):1621-7. [PubMed: 9884249].

14. Knoll G. Trends in kidney transplantation over the past decade. Drugs. 2008;68 Suppl 1:3-10. [PubMed:18442296].

15. Baczkowska T, Durlik M. Calcineurin inhibitor sparing immunosuppressive regimens in kidney allograft recipients. Pol Arch Med Wewn. 2009;119(5):318-25. [PubMed: 19579814].

16. Mengel M, Chapman JR, Cosio FG, Cavaille-Coll MW, Haller H, Halloran $\mathrm{PF}$, et al. Protocol biopsies in renal transplantation: insights into patient management and pathogenesis. Am J Transplant. 2007;7(3):512-7. doi: 10.1111/j.1600-6143.2006.01677.x. [PubMed: 17250556].

17. Levy G, Thervet E, Lake J, Uchida K, Consensus on Neoral CRITG. Patient management by Neoral C(2) monitoring: an international consensus statement. Transplantation. 2002;73(9 Suppl):S12-8. [PubMed: 12023608]

18. Press RR, Ploeger BA, den Hartigh J, van der Straaten T, van Pelt H, Danhof M, et al. Explaining variability in ciclosporin exposure in adult kidney transplant recipients. Eur J Clin Pharmacol. 2010;66(6):579-90. doi: 10.1007/s00228-010-0810-9. [PubMed: 20354687].

19. Steimer W. Performance and specificity of monoclonal immunoassays for cyclosporine monitoring: how specific is specific? Clin Chem. 1999;45(3):371-81. [PubMed: 10053038].

20. Schutz E, Svinarov D, Shipkova M, Niedmann PD, Armstrong VW, Wieland E, et al. Cyclosporin whole blood immunoassays (AXSYM, CEDIA, and Emit): a critical overview of performance character- istics and comparison with HPLC. Clin Chem. 1998;44(10):2158-64 [PubMed: 9761250].

21. Holt DW, Jones K, Lee T, Stadler P, Johnston A. Quality assessment issues of new immunosuppressive drugs and experimental experience. Ther Drug Monit. 1996;18(4):362-7. [PubMed: 8857551].

22. Holt DW, Johnston A, Kahan BD, Morris RG, Oellerich M, Shaw LM. New approaches to cyclosporine monitoring raise further concerns about analytical techniques. Clin Chem. 2000;46(6 Pt 1):872-4 [PubMed: 10839783].

23. Batiuk TD, Pazderka F, Enns J, DeCastro L, Halloran PF. Cyclosporine inhibition of calcineurin activity in human leukocytes in vivo is rapidly reversible. J Clin Invest. 1995;96(3):1254-60. doi: 10.1172/JCI118159. [PubMed: 7657799].

24. von Ahsen N, Helmhold M, Schutz E, Eisenhauer T, Armstrong VW, Oellerich M. Cyclosporin A trough levels correlate with serum lipoproteins and apolipoproteins: implications for therapeutic drug monitoring of cyclosporin A. Ther Drug Monit. 1997;19(2):1405. [PubMed: 9108640].

25. Jorgensen KA, Koefoed-Nielsen PB, Karamperis N. Calcineurin phosphatase activity and immunosuppression. A review on the role of calcineurin phosphatase activity and the immunosuppressive effect of cyclosporin A and tacrolimus. Scand JImmunol. 2003;57(2):938. [PubMed: 12588654].

26. Saas P, Tiberghien P. Dendritic cells: to where do they lead? Transplantation. 2002;73(1 Suppl):S12-5. [PubMed: 11810054].

27. Cattaneo D, Perico N, Remuzzi G. From pharmacokinetics to pharmacogenomics: a new approach to tailor immunosuppressive therapy. Am J Transplant. 2004;4(3):299-310. [PubMed: 14961981].

28. Falck P, Asberg A, Guldseth H, Bremer S, Akhlaghi F, Reubsaet JL, et al. Declining intracellular T-lymphocyte concentration of cyclosporine a precedes acute rejection in kidney transplant recipients. Transplantation. 2008;85(2):179-84. doi: 10.1097/TP.ob013e31815feede. [PubMed: 18212621]

29. Caruso R, Perico N, Cattaneo D, Piccinini G, Bonazzola S, Remuzzi $\mathrm{G}$, et al. Whole-blood calcineurin activity is not predicted by cyclosporine blood concentration in renal transplant recipients. Clin Chem. 2001;47(9):1679-87. [PubMed: 11514403].

30. Vitko S, Tedesco H, Eris J, Pascual J, Whelchel J, Magee JC, et al. Everolimus with optimized cyclosporine dosing in renal transplant recipients: 6-month safety and efficacy results of two randomized studies. Am J Transplant. 2004;4(4):626-35. doi: 10.1111/j.16006143.2004.00389.x. [PubMed: 15023156].

31. Keown PA. New concepts in cyclosporine monitoring. Curr Opin Nephrol Hypertens. 2002;11(6):619-26. doi: 10.1097/01.mnh.0000040047.33359.86. [PubMed:12394607].

32. Citterio F, Scata MC, Romagnoli J, Nanni G, Castagneto M. Results of a three-year prospective study of $\mathrm{C} 2$ monitoring in long-term renal transplant recipients receiving cyclosporine microemulsion. Transplantation. 2005;79(7):802-6. [PubMed:15818322].

33. Perico N, Ruggenenti P, Gotti E, Gaspari F, Cattaneo D, Valente U, et al. In renal transplantation blood cyclosporine levels soon after surgery act as a major determinant of rejection: insights from the MY.S.S. trial. Kidney Int. 2004;65(3):1084-90. doi: 10.1111/j.15231755.2004.00471.x. [PubMed: 14871429].

34. Rodrigo E, Ruiz JC, Angeles de Cos M, Ruiz J, Gago M, Pinera C, et al. Correlation of $\mathrm{CO}$ and $\mathrm{C} 2$ levels with cyclosporine side effects in kidney transplantation. Transplant Proc. 2009;41(6):2328-31. doi: 10.1016/j.transproceed.2009.06.155. [PubMed:19715910].

35. Mendez A, Monforte V, Berastegui C, Lopez-Meseguer M, Bravo C Pou L, et al. High intra-individual variability of cyclosporine pharmacokinetics in lung transplant recipients without cystic fibrosis. Clin Transplant. 2014;28(6):743-8. doi: 10.1111/ctr.12371. [PubMed: 24708188].

36. Takasugi M, Takasugi JK, Barba L. Monitoring changes in cyclosporine dosage by trough level testing. Clin Transplant 
1995;9(2):98-105. [PubMed: 7599410].

37. Hami M, Mojahedi MJ, Naghibi M, Shakeri MT, Sharifipour F. Cyclosporine trough levels and its side effects in kidney transplant recipients. Iran J Kidney Dis. 2010;4(2):153-7. [PubMed: 20404428].

38. Matas AJ, Smith JM, Skeans MA, Thompson B, Gustafson SK, Schnitzler MA, et al. OPTN/SRTR 2012 Annual Data Report: kidney. Am J Transplant. 2014;14 Suppl 1:11-44. doi: 10.1111/ajt.12579. [PubMed: 24373166].

39. Marin JG, Levine M, Ensom MH. Is C2 monitoring or another limited sampling strategy superior to CO monitoring in improving clinical outcomes in adult liver transplant recipients? Ther Drug Monit. 2006;28(5):637-42. doi: 10.1097/01.ftd.0000243965.97964.ca. [PubMed: 17038878].

40. Halloran PF, Helms LM, Kung L, Noujaim J. The temporal profile of calcineurin inhibition by cyclosporine in vivo. Transplantation. 1999;68(9):1356-61. [PubMed:10573076].

41. Stein CM, Murray JJ, Wood AJ. Inhibition of stimulated interleukin2 production in whole blood: a practical measure of cyclosporine effect. Clin Chem. 1999;45(9):1477-84. [PubMed:10471650].

42. Hartel C, Fricke L, Schumacher N, Kirchner H, Muller-Steinhardt M. Delayed cytokine mRNA expression kinetics after T-lymphocyte costimulation: a quantitative measure of the efficacy of cyclosporin A-based immunosuppression. Clin Chem. 2002;48(12):2225-31. [PubMed: 12446480].

43. Delgado DH, Rao V, Hamel J, Miriuka S, Cusimano RJ, Ross HJ. Monitoring of cyclosporine 2-hour post-dose levels in heart transplantation: improvement in clinical outcomes. J Heart Lung Transplant. 2005;24(9):1343-6. doi: 10.1016/j.healun.2004.08.002. [PubMed: 16143255].

44. Cantarovich M, Fitchett D, Latter DA. Cyclosporine trough levels, acute rejection, and renal dysfunction after heart transplantation. Transplantation. 1995;59(3):444-7. [PubMed: 7871582].

45. Cole E, Maham N, Cardella C, Cattran D, Fenton S, Hamel J, et al. Clinical benefits of neoral C2 monitoring in the long-term management of renal transplant recipients. Transplantation. 2003;75(12):2086-90. doi:10.1097/01.TP.0000068868.01424.61. [PubMed: 12829917].

46. Di Paolo S, Teutonico A, Schena A, Infante B, Stallone G, Grandaliano $\mathrm{G}$, et al. Conversion to $\mathrm{C} 2$ monitoring of cyclosporine A exposure in maintenance kidney transplant recipients: results at 3 years. Am J Kidney Dis. 2004;44(5):886-92. [PubMed: 15492955].

47. Sitland TD, Kiberd B, Lawen J, Belitsky P. Conversion Of Long Term, Neoral Treated Kidney Transplant Recipients From Co To C2 Monitoring. Am J Transplant Suppl. 2002;2:232.

48. Nashan B, Cole E, Levy G, Thervet E. Clinical validation studies of Neoral C(2) monitoring: a review. Transplantation. 2002;73(9 Suppl):S311. [PubMed: 12023607].

49. Cole E, Midtvedt K, Johnston A, Pattison J, O'Grady C. Recommendations for the implementation of Neoral C(2) monitoring in clinical practice. Transplantation. 2002;73(9 Suppl):S19-22. [PubMed: 12023609].

50. Oellerich M, Armstrong VW. Two-hour cyclosporine concentration determination: an appropriate tool to monitor neoral therapy? Ther Drug Monit. 2002;24(1):40-6. [PubMed: 11805721].

51. Grant D, Kneteman N, Tchervenkov J, Roy A, Murphy G, Tan A, et al. Peak cyclosporine levels ( $\max$ ) correlate with freedom from liver graft rejection: results of a prospective, randomized comparison of neoral and sandimmune for liver transplantation (NOF-8). Transplantation. 1999;67(8):1133-7. [PubMed:10232563].

52. Levy G, Burra P, Cavallari A, Duvoux C, Lake J, Mayer AD, et al. Improved clinical outcomes for liver transplant recipients using cyclosporine monitoring based on 2-hr post-dose levels (C2). Transplantation. 2002;73(6):953-9. [PubMed: 11923699].

53. Cantarovich M, Besner JG, Barkun JS, Elstein E, Loertscher R. Twohour cyclosporine level determination is the appropriate tool to monitor Neoral therapy. Clin Transplant. 1998;12(3):243-9. [PubMed: 9642517].
54. Cantarovich M, Elstein E, de Varennes B, Barkun JS. Clinical benefit of neoral dose monitoring with cyclosporine 2-hr post-dose levels compared with trough levels in stable heart transplant patients. Transplantation. 1999;68(12):1839-42. [PubMed: 10628760].

55. Kovarik JM, Kalbag J, Figueiredo J, Rouilly M, Frazier OL, Rordorf C. Differential influence of two cyclosporine formulations on everolimus pharmacokinetics: a clinically relevant pharmacokinetic interaction. J Clin Pharmacol. 2002;42(1):95-9. [PubMed: 11808830].

56. Filler G, Lepage N, Delisle B, Mai I. Effect of cyclosporine on mycophenolic acid area under the concentration-time curve in pediatric kidney transplant recipients. Ther Drug Monit. 2001;23(5):514-9. [PubMed: 11591896].

57. Sindhi R, LaVia MF, Paulling E, McMichael J, Burckart G, Shaw S, et al. Stimulated response of peripheral lymphocytes may distinguish cyclosporine effect in renal transplant recipients receiving a cyclosporine+rapamycin regimen. Transplantation. 2000;69(3):4326. [PubMed: 10706056].

58. Levy GA. C2 monitoring strategy for optimising cyclosporin immunosuppression from the Neoral formulation. BioDrugs. 2001;15(5):279-90. [PubMed: 11437692].

59. Einecke G, Mai I, Fritsche L, Slowinski T, Waiser J, Glander P, et al. Cyclosporin C2hour monitoring after renal transplantation. Int J Clin Pharmacol Ther. 2003;41(10):477-81. [PubMed: 14703954].

60. Birsan T, Loinig C, Bodingbauer M, Wekerle T, Rockenschaub S, Berlakovich $\mathrm{G}$, et al. Comparison between Co and C2 monitoring in de novo renal transplant recipients: retrospective analysis of a single-center experience. Transplantation. 2004;78(12):1787-91. [PubMed: 15614152].

61. Mahalati K, Belitsky P, Sketris I, West K, Panek R. Neoral monitoring by simplified sparse sampling area under the concentrationtime curve: its relationship to acute rejection and cyclosporine nephrotoxicity early after kidney transplantation. Transplantation. 1999;68(1):55-62. [PubMed: 10428267].

62. Banner NR, David OJ, Leaver N, Davis J, Breen J, Johnston A, et al. Pharmacokinetics of oral cyclosporine (Neoral) in heart transplant recipients during the immediate period after surgery. Transpl Int. 2002;15(12):649-54. doi: 10.1007/s00147-002-0491-0. [PubMed: 12478413].

63. Ray E, Keogh AM, McLachlan AJ, Akhlaghi F. Cyclosporin C2 and Co concentration monitoring in stable, long-term heart transplant recipients receiving metabolic inhibitors. J Heart Lung Transplant. 2003;22(7):715-22. doi: 10.1016/s1053-2498(02)00649-6.

64. Mahalati K, Lawen J, Kiberd B, Belitsky P. Is 3-hour cyclosporine blood level superior to trough level in early post-renal transplantation period? J Urol. 2000;163(1):37-41. [PubMed: 10604309].

65. Kahan BD. Therapeutic drug monitoring of cyclosporine: 20 years of progress. 36. Elsevier; 2004.

66. Wong HS, Morad Z. Neoral (cyclosporine) C2 monitoring in renal transplant recipients: a single-center experience in Asia. Transplant Proc. 2003;35(1):230-1. [PubMed: 12591376].

67. Dunn CJ, Wagstaff AJ, Perry CM, Plosker GL, Goa KL. Cyclosporin: an updated review of the pharmacokinetic properties, clinical efficacy and tolerability of a microemulsion-based formulation (neoral)1 in organ transplantation. Drugs. 2001;61(13):1957-2016. [PubMed: 11708766].

68. Christiaans M, van Duijnhoven E, Beysens T, Undre N, Schafer A, van Hooff J. Effect of breakfast on the oral bioavailability of tacrolimus and changes in pharmacokinetics at different times posttransplant in renal transplant recipients. Transplant Proc. 1998;30(4):1271-3. [PubMed: 9636516].

69. Morris RG, Russ GR, Cervelli MJ, Juneja R, McDonald SP, Mathew TH Comparison of trough, 2-hour, and limited AUC blood sampling for monitoring cyclosporin (Neoral) at day 7 post-renal transplantation and incidence of rejection in the first month. Ther Drug Monit. 
2002;24(4):479-86. [PubMed: 12142630].

70. Keown P, Landsberg D, Halloran P, Shoker A, Rush D, Jeffery J, et al. A randomized, prospective multicenter pharmacoepidemiologic study of cyclosporine microemulsion in stable renal graft recipients. Report of the Canadian Neoral Renal Transplantation Study Group. Transplantation. 1996;62(12):1744-52. [PubMed: 8990355].

71. Mahalati K, Belitsky P, West K, Kiberd B, Fraser A, Sketris I, et al. Approaching the therapeutic window for cyclosporine in kidney transplantation: a prospective study. J Am Soc Nephrol. 2001;12(4):828-33. [PubMed: 11274245].

72. Lindholm A, Kahan BD. Influence of cyclosporine pharmacokinetics, trough concentrations, and AUC monitoring on outcome after kidney transplantation. Clin Pharmacol Ther. 1993;54(2):205-18. [PubMed: 8354028].

73. Senel MF, Van Buren CT, Welsh M, Kahan BD. Impact of early cyclosporin average blood concentration on early kidney transplant failure. Transpl Int. 1998;11(1):46-52. [PubMed: 9503554].

74. Johnston A, Sketris I, Marsden JT, Galustian CG, Fashola T, Taube D, et al.A limited sampling strategy for the measurement of cyclosporine AUC. Transplant Proc. 1990;22(3):1345-6. [PubMed: 2349694].

75. Grevel J, Kahan BD. Abbreviated kinetic profiles in area-underthe-curve monitoring of cyclosporine therapy. Clin Chem. 1991;37(11):1905-8. [PubMed: 1934462].

76. Amante AJ, Kahan BD. Abbreviated area-under-the-curve strategy for monitoring cyclosporine microemulsion therapy in immediate posttransplant period. Clin Chem. 1996;42(8 Pt 1):1294-6. [PubMed: 8697597].

77. Canadian Neoral Renal Transplantation Study G. Absorption profiling of cyclosporine microemulsion (neoral) during the first 2 weeks after renal transplantation. Transplantation. 2001;72(6):102432. [PubMed: 11579295].

78. Woillard JB, Lebreton V, Neely M, Turlure P, Girault S, Debord J, et al. Pharmacokinetic tools for the dose adjustment of ciclosporin in haematopoietic stem cell transplant patients. $\mathrm{Br} J$ Clin Pharmacol. 2014;78(4):836-46. doi: 10.1111/bcp.12394. [PubMed: 24698009].

79. Einecke G, Mai I, Fritsche L, Slowinski T, Waiser J, Neumayer HH, et al. The value of $\mathrm{C} 2$ monitoring in stable renal allograft recipients on maintenance immunosuppression. Nephrol Dial Transplant. 2004;19(1):215-22. [PubMed: 14671060].

80. Lemahieu WP, Maes BD, Verbeke K, Vanrenterghem YF. Alterations of CYP3A4 and P-glycoprotein activity in vivo with time in renal graft recipients. Kidney Int. 2004;66(1):433-40. doi: 10.1111/j.15231755.2004.00750.x. [PubMed: 15200453].

81. Hebert MF. Contributions of hepatic and intestinal metabolism and P-glycoprotein to cyclosporine and tacrolimus oral drug delivery. Adv Drug Deliv Rev. 1997;27(2-3):201-14. [PubMed: 10837558].

82. Lampen A, Christians U, Bader A, Hackbarth I, Sewing KF. Drug interactions and interindividual variability of ciclosporin metabolism in the small intestine. Pharmacology. 1996;52(3):159-68. [PubMed: 8849485].

83. Lown KS, Mayo RR, Leichtman AB, Hsiao HL, Turgeon DK, SchmiedlinRen $\mathrm{P}$, et al. Role of intestinal P-glycoprotein (mdr1) in interpatient variation in the oral bioavailability of cyclosporine. Clin Pharmacol Ther. 1997;62(3):248-60. doi: 10.1016/S0009-9236(97)90027-8. [PubMed: 9333100].

84. Mueller EA, Kallay Z, Kovarik JM, Richard F, Wiesinger O, Schmidt $\mathrm{K}$, et al. Bile-independent absorption of cyclosporine from a microemulsion formulation in liver transplant patients. Transplantation. 1995;60(5):515-7. [PubMed: 7676504].

85. Xin HW, Liu HM, Li YQ, Huang H, Zhang L, Yu AR, et al. Association of CYP3A4*18B and CYP3A5*3 polymorphism with cyclosporine-related liver injury in Chinese renal transplant recipients. Int J Clin Pharmacol Ther. 2014;52(6):497-503. doi: 10.5414/CP202042. [PubMed: 24691060].

86. Barnard JB, Thekkudan J, Richardson S, Bittar MN, Martyszczuck R, Hasan J, et al. Cyclosporine profiling with C2 and Co monitoring improves outcomes after heart transplantation. J Heart Lung Transplant. 2006;25(5):564-8. doi:10.1016/j.healun.2005.12.005. [PubMed 16678036].

87. Thervet E, Pfeffer P, Scolari MP, Toselli L, Pallardo LM, Chadban S, et al. Clinical outcomes during the first three months posttransplant in renal allograft recipients managed by $\mathrm{C} 2$ monitoring of cyclosporine microemulsion. Transplantation. 2003;76(6):903-8. doi: 10.1097/01.TP.0000089006.00653.64. [PubMed: 14508352].

88. Levy GA, Lake JR, Beauregard-Zollinger L, Prestele H. Improved Clinical Outcomes for Liver Transplant Recipients Using Cyclosporine Blood Level Monitoring Based on Two-Hour Post-Dose Levels. Transplantation. 2000;69(Supplement):S387. doi: 10.1097/00007890200004271-01059.

89. Morton JM, Aboyoun CL, Malouf MA, Plit ML, Glanville AR. Enhanced clinical utility of de novo cyclosporine C2 monitoring after lung transplantation. J Heart Lung Transplant. 2004;23(9):1035-9. doi: 10.1016/j.healun.2003.08.008. [PubMed: 15454168].

90. Glanville AR, Hopkins PM, Aboyoun CL, Chhajed PN, Plit ML, Malouf MA. Clinical utility of cyclosporin C2 monitoring after lung transplantation (LTX). J Heart Lung Transplant. 2002;21(1):143. doi 10.1016/s1053-2498(01)00680-5.

91. Villamil F, Pollard S. C2 monitoring of cyclosporine in de novo liver transplant recipients: the clinician's perspective. Liver Transpl. 2004;10(5):577-83. doi: 10.1002/lt.20112. [PubMed: 15108248].

92. Press RR, de Fijter JW, Guchelaar HJ. Individualizing calcineurin inhibitor therapy in renal transplantation-current limitations and perspectives. Curr Pharm Des. 2010;16(2):176-86. [PubMed: 20205663].

93. Lindh JD, Andersson ML, Eliasson E, Bjorkhem-Bergman L. Seasonal variation in blood drug concentrations and a potential relationship to vitamin D. Drug Metab Dispos. 2011;39(5):933-7. doi: 10.1124/dmd.111.038125. [PubMed: 21349923].

94. Ashavaid T, Raje H, Shalia K, Shah B. Effect of gene polymorphisms on the levels of calcineurin inhibitors in Indian renal transplant recipients. Indian J Nephrol. 2010;20(3):146-51. doi: 10.4103/09714065.70846. [PubMed: 21072155].

95. Tang HL, Ma LL, Xie HG, Zhang T, Hu YF. Effects of the CYP3A5*3 variant on cyclosporine exposure and acute rejection rate in renal transplant patients: a meta-analysis. Pharmacogenet Genomics. 2010;20(9):525-31. doi: 10.1097/FPC.0b013e32833ccd56. [PubMed: 20588203].

96. Zacher T, Thiele B, Wassmuth R, Albert FW. Cyclosporine A sensitivity in vitro and P-glycoprotein expression in patients on dialysis and after kidney transplantation. Transpl Immunol. 2000;8(2):14750. [PubMed: 11005322].

97. Zhang Y, Li JL, Fu Q, Wang XD, Liu LS, Wang CX, et al. Associations of ABCB1, NFKB1, CYP3A, and NR112 polymorphisms with cyclosporine trough concentrations in Chinese renal transplant recipients. Acta Pharmacol Sin. 2013;34(4):555-60. doi: 10.1038/aps.2012.200. [PubMed: 23503472].

98. Einollahi B, Rostami Z, Teimoori M. Human leukocyte antigen variation among Iranian renal transplant recipients. J Nephropathol. 2012;1(3):164-9. doi: 10.5812/nephropathol.8114. [PubMed: 24475410].

99. Nemati E, Taheri S, Pourfarziani V, Einollahi B. Human leukocyte antigen (HLA) B-27 and older age are associated with augmented cyclosporine blood bioavailability in renal allograft recipients: an attempt toward individualization of immunosuppression. Ann Transplant. 2008;13(2):32-6. [PubMed: 18566557].

100. Elens L, Hesselink DA, Bouamar R, Budde K, de Fijter JW, De Meyer $\mathrm{M}$, et al. Impact of $\mathrm{POR}^{*} 28$ on the pharmacokinetics of tacrolimus and cyclosporine A in renal transplant patients. Ther Drug Monit. 2014;36(1):71-9. doi: 10.1097/FTD.ob013e31829da6dd. [PubMed: 24061445].

101. Einollahi B, Teimoori M, Rostami Z. Change of Cyclosporine Absorption over the Time after Kidney Transplantation. Nephrourol Mon 
2012;4(2):470-4. doi: 10.5812/numonthly.2437. [PubMed: 23573469].

102. Sanchez R, Picard N, Mouly-Bandini A, Chalvignac V, Lacarelle B, Sampol-Manos E. Severe decrease of cyclosporine levels in a heart transplant recipient receiving the direct thrombin inhibitor argatroban. Ther Drug Monit. 2014;36(3):273-7. doi: 10.1097/FTD.0000000000000026. [PubMed: 24365983].

103. Tornatore KM, Brazeau D, Dole K, Danison R, Wilding G, Leca N, et al. Sex differences in cyclosporine pharmacokinetics and ABCB1 gene expression in mononuclear blood cells in African American and Caucasian renal transplant recipients. J Clin Pharmacol. 2013;53(10):1039-47. doi:10.1002/jcph.123. [PubMed: 23908147].

104. Roos K, Gotthardt D, Giese T, Schnitzler P, Stremmel W, Czock D, et al. Pharmacodynamic monitoring of immunosuppressive effects indicates reduced cyclosporine activity during telaprevir therapy. Liver Transpl. 2014;20(9):1106-17. doi: 10.1002/lt.23925. [PubMed: 24890314].

105. Carrier M, White M, Pellerin M, Pelletier GB, Pelletier LC. Comparison of Neoral and Sandimmune cyclosporine for induction of immunosuppression after heart transplantation. Can J Cardiol. 1997;13(5):469-73. [PubMed: 9179085].

106. Moes DJ, Swen JJ, den Hartigh J, van der Straaten T, van der Heide JJ, Sanders JS, et al. Effect of CYP3A4*22, CYP3A5*3, and CYP3A Combined Genotypes on Cyclosporine, Everolimus, and Tacrolimus Pharmacokinetics in Renal Transplantation. CPT Pharmacometrics Syst Pharmacol. 2014;3:ee100. doi: 10.1038/psp.2013.78. [PubMed: 24522145].

107. Zhou H, Gao Y, Cheng XL, Li ZD. Population pharmacokinetics of cy- closporine A based on NONMEM in Chinese allogeneic hematopoietic stem cell transplantation recipients. Eur J Drug Metab Pharmacokinet. 2012;37(4):271-8. doi: 10.1007/s13318-012-0087-8. [PubMed: 22446981].

108. Cooney GF, Jeevanandam V, Choudhury S, Feutren G, Mueller EA, Eisen HJ. Comparative bioavailability of Neoral and Sandimmune in cardiac transplant recipients over 1 year. 30. Elsevier; 1998.

109. Tan KK, Trull AK, Hue KL, Best NG, Wallwork J, Higenbottam TW. Pharmacokinetics of cyclosporine in heart and lung transplant candidates and recipients with cystic fibrosis and Eisenmenger's syndrome. Clin Pharmacol Ther. 1993;53(5):544-54. [PubMed: 8491066].

110. Kalyoncu M, Topaloglu R, Bayrakci U, Bakkaloglu A, Besbas N, Ozaltin $\mathrm{F}$, et al. Cyclosporine drug monitoring with $\mathrm{C} 0$ and $\mathrm{C} 2$ concentrations in children with stable renal allograft function. Pediatr Transplant. 2006;10(2):168-71. doi: 10.1111/j.1399-3046.2005.00436.x. [PubMed: 16573602].

111. Sommerer C, Giese T, Meuer S, Zeier M. Pharmacodynamic monitoring of calcineurin inhibitor therapy: is there a clinical benefit? Nephrol Dial Transplant. 2009;24(1):21-7. doi: 10.1093/ndt/gfn556. [PubMed: 18842676].

112. Einollahi B, Teimoori M. Cyclosporine trough level monitoring. Iran J Kidney Dis. 2011;5(3):211-2. [PubMed: 21525586].

113. Marquet P. Pretransplantation calcineurin activity: towards individualized therapy? Liver Int. 2009;29(10):1454-6. doi: 10.1111/j.14783231.2009.02146.x. [PubMed: 19811612]. 